\title{
Engineering Evaluation of Lateritic Soils of Failed Highway Sections in Southwestern Nigeria
}

\author{
Ademila, Omowumi \\ Department of Earth Sciences, Adekunle Ajasin University, Akungba-Akoko, Nigeria \\ Email: omowumi.ademila@aaua.edu.ng
}

\begin{abstract}
Engineering impact of lateritic soils underlying some failed roads and highways in Akure, southwestern Nigeria was investigated with the aim of evaluating its competence for highway pavement structures. Twenty-eight bulk soil samples of lateritic soil were collected from five failed sections and two stable sections for index and strength tests related to road construction. The soils from the stable sections have higher specific gravity (2.73-2.86) with less amount of clay (23.68\%) and indicate A-6 and A-2-6 on the AASHTO classification system compared to soils from the failed sections of A-7-6 implying poor quality subgrade. High water absorption capability, high proportion of fines $(>57 \%)$ and high values of linear shrinkage $(>8 \%)$ of soils from failed sections caused pore water pressures to develop, resulting in loss of strength with percentage reduction in strength up to $79 \%$. The predominance of fines in the lateritic soils, low California bearing ratio (14-32\% unsoaked; $3-11 \%$ soaked) and low strength characteristics (angle of friction: 13-17 ${ }^{\circ}$, shear strength: 79-108 $\mathrm{kN} / \mathrm{m} 2$ ) are responsible for the degree of instability witnessed. The poor geotechnical properties of the lateritic soils of failed sections imply that they are unsuitable for use as subgrade materials in road construction and even in other engineering structures. Importance of detailed sampling of lateritic soils is stressed for correct assessment of highway subgrade soils. The results of this study will be useful in rehabilitation and reconstruction works of the failed sections of the road and proper documentation of this investigation is recommended for future pavement design and construction of roads.
\end{abstract}

Keywords: Engineering impact, lateritic soil, highway pavement, strength characteristics, stabilization.

\section{Introduction}

All engineering structures are constructed on rock or soil, while the nature and characteristics of the soil influence their engineering performance. Globally, engineering structures are constructed with the expectation to stand a test of time [1]. However, there is lack of in-depth understanding of the geotechnical properties of soils which is a precondition for its use in civil engineering construction works. Road network plays a vital role in socio-economic development of many nations. Nigeria is among the countries with the highest records of road accidents with incessant loss of lives and properties due to bad roads. The design and construction of roads in Nigeria are finalized without assessing the geology and geotechnical behaviour of the underlying soils. This has led to failure encountered in roads or highways. The relationship between highway pavements and their foundation soils cannot be overemphasized in any nation that desires to develop. In all cases, the geological history of any locality has very strong influence on the derived engineering soils [2]. Despite continuous rehabilitation and reconstruction of the failed sections along Kajola-Oda Road, pavement distress occurs shortly after repairs.

Lateritic soils are the most common surface deposits occurring in the tropical and subtropical regions of the world, enriched in iron and aluminium and developed by intensive and long lasting weathering of the underlying parent rock [3]. Nigeria is the only nation where laterites serve as the perfect soil materials to solve all construction problems especially in construction of earth dams, highways, embankments, airfields and foundation materials to support structures without considering its classification as problem and non-problem types and the actual field geotechnical performance of the 
soils. According to Ref. [4], laterite soils are formed in hot, wet tropical regions with annual rainfall between 750 and $3000 \mathrm{~mm}$ (usually in area with a significant dry season) on a variety of different types of rocks with high iron content. Problem laterites are those that have characteristics of being problematic in road construction. These types of soils are easily noticed in highway and airfield pavement where they are used as sub-base materials, resulting in pavement swelling, depression and lateral movements in the presence of water even under moderate wheel loads. They are characterized by high natural water contents and liquid limits, low natural densities and friable and/or crumble structure [3]. Hence, laterites which do not have these properties are non-problem types. In the tropical part of the world like Nigeria, lateritic soil is used as a road making material and it forms the sub-grade of most tropical roads, sub-base and base course for low cost roads which tend to carry low to medium traffic. Furthermore, they are used as building materials for moulding bricks and plastering.

Failures on Nigeria highways are generally due to poor geotechnical properties of the underlying soils which constitute the entire road pavement. A review of the factors influencing the performance of a pavement has been described by Ref. [5]; which includes different types of road failure ranging from cracks, potholes to road-cut leading to differential heave of the pavement material causing frequent bumps on the highways. [6] studied the geotechnical basis for failure of sections of the Lagos-Ibadan expressway southwestern, Nigeria. They concluded that the soils underlying the failed sections are more mechanically stable than those beneath the stable section. They therefore suggested that mechanical properties cannot be used to determine the stability of road pavements and recommended further investigation of the geotechnical properties of as many subgrade soils as possible to explain the influence of geotechnical and geological factors. When lateritic soil contains a large amount of clay materials, its strength, integrity and stability cannot be secured under load in the presence of water.

The geotechnical properties of a soil such as grain size distribution, plasticity, compressibility, shear strength, permeability, soil compaction, California bearing ratio and so on are used in determining the behaviour of soil when subjected to loads. These properties can be evaluated by correct laboratory or insitu tests. Failure of lateritic roads in Nigeria and other developing countries has stressed the need for detailed geotechnical evaluation of lateritic soil prior its use in road construction in order to choose appropriate soil materials for the pavement structure. Continuous failure of Kajola-Oda Road shortly after reconstruction and rehabilitation which includes removal and replacement of the unstable soil material has prompted this research work to identify factor(s) responsible for the incessant failure.

\section{Location and Geology of the Study Area}

The study area lies within latitudes $7^{\circ} 10^{\prime} \mathrm{N}$ and $7^{\circ} 19^{\prime} \mathrm{N}$ and longitudes $5^{\circ} 07^{\prime} \mathrm{E}$ and $5^{\circ} 14^{\prime} \mathrm{E}$. It covers an area extent of about $13 \mathrm{Km}^{2}$ (Fig. 1). The town is situated in the humid tropical region of Nigeria, characterized by alternating wet and dry seasons with a mean annual rainfall of over $1500 \mathrm{~mm}$. The area is drained by two major Rivers 'Ala 1 and Ala 2' which are seasonal and have a length of about $14.8 \mathrm{Km}$. The two rivers dominate the drainage system of the study area and it's mainly dendritic. It has an average elevation of about $370 \mathrm{~m}$. The study area falls within the Precambrian Basement Complex rocks of southwestern Nigeria [7]. Charnockites, granite gneiss and migmatitic rocks are the predominant rock types in the study area (Fig. 2).

\section{$3 \quad$ Materials and Methods}

This research includes detailed geological field mapping in order to ascertain the local geology of the area and identification of failed and stable sections of the studied road. On the field, the rock and soil exposures were observed and described. Twenty-eight bulk samples from the sub-grade soils were collected from seven trial pits. Twenty samples from five failed sections and eight samples from two stable sections of the road serving as control were obtained at sampling depths of $0.5 \mathrm{~m}$ to $2 \mathrm{~m}$ to obtain true representative samples of the sub-grade and sub-base materials. All the soil samples were carefully labeled in sample bags and then taken to the laboratory in sealed polythene bags to prevent contamination and loss of moisture. The natural moisture content was determined immediately in the laboratory. Soil samples were air dried for two weeks to allow partial removal of natural water before other analysis. After the drying, lumps in the samples were gently grinded with minimal pressure not to 
reduce the sizes of the individual particles. The following laboratory tests were conducted on the samples: natural moisture content, specific gravity, consistency limits, linear shrinkage, grain size distribution, compaction, California bearing ratio (CBR), unconfined compressive strength and shear strength. These laboratory analyses were carried out according to British Standard Methods of test for soils for civil engineering purposes [8] and [9]. Samples for grain size analysis were soaked in a weak calgon solution to facilitate disaggregation during wet sieving.

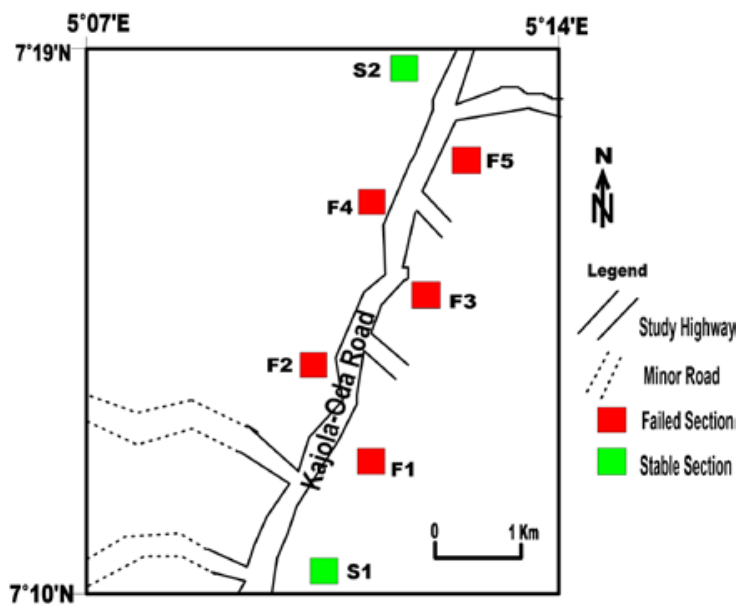

Figure 1. Location map of the study area showing the failed and stable sections of the road.

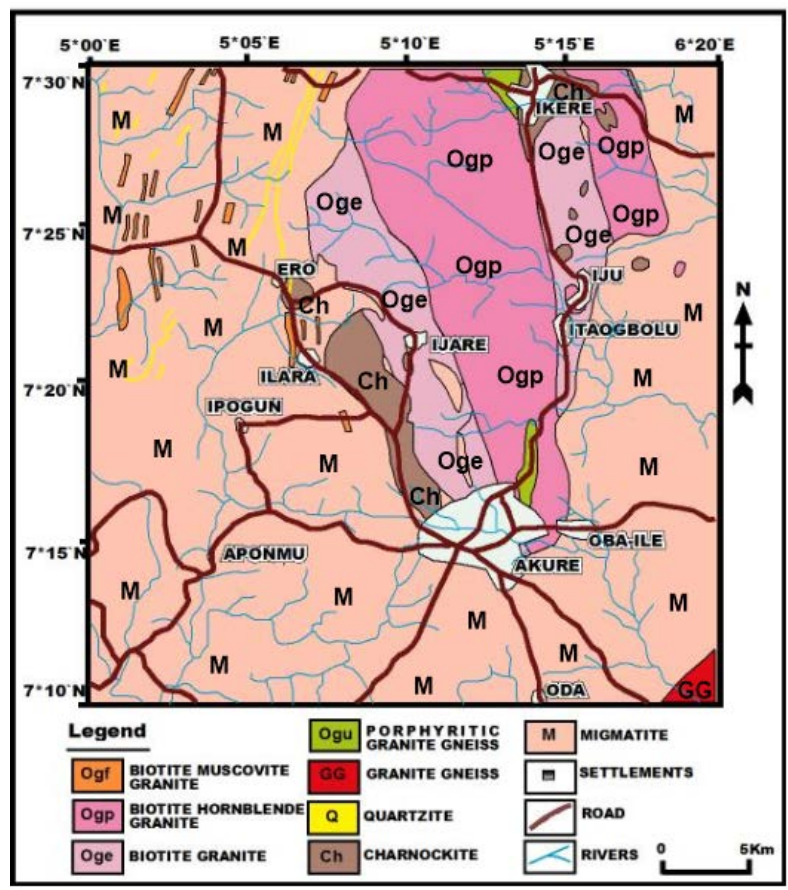

Figure 2. Geological Map of the study area. 


\section{Results and Discussion}

Satisfactory pavement performance is largely attributed to a good foundation that provides adequate strength and low compressibility. This is dependent upon the index and engineering properties of the underlying base and subgrade layers that serve as the foundation of pavement structures to distribute loads uniformly and effectively.

\subsection{Index Properties}

The results of the index tests carried out on the soil samples are summarized in Table 1 which are important parameters in soil engineering calculation.

\subsubsection{Natural moisture content}

The natural moisture content of the analyzed soil samples from the failed sections of the highway varied from $12.3-23.3 \%$ (Table 1) while, those from the stable sections varied from $10.6-12.7 \%$. This shows that soils from the failed sections have high natural moisture content, because these values are higher than the average range $(5-15 \%)$ specified by Ref. [10] for engineering construction. This is an indication of high water adsorption capability of the soil material. Although, the performance of lateritic soil may be influenced by climate, hydrological condition of the area in which the road is to be constructed and the topography of the area [11]. These factors are responsible for the variation in the natural moisture contents of the soils of the study area. Natural moisture content is used as an indicator for the shear strength of soils, as increase in the moisture content results in a decrease in the shear strength of the material.

\subsubsection{Specific gravity}

The specific gravity of the soils ranged from $2.58-2.86$ (Table 1). It can be seen that soils from stable sections have higher specific gravity ( $\mathrm{Gs}=2.73-2.86)$ with less amount of clay $(23.68 \%)$, and fall under group A-6 (S1) and A-2-6 (S2) of American Association of State Highways and Transport Officials [12] classification rated good to fair subgrade material. On the basis of this specific gravity, the studied soils can be classified as inorganic soils [13]. Specific gravity is a measure of the weight of that particular soil to the weight of an equal volume of water. It is an indication of the saturated surface dry condition. It is also a function of the amount of voids and quartz-like material in the soil. Ref. [14] noted that most clay minerals have specific gravities that fall within a general range (1.6 - 2.9). The higher the specific gravity, the higher is the degree of laterization of the soil. This indicates that soils from stable sections show higher degree of laterization than soils from failed sections. The results show that the soils from the stable sections majorly contain quartz mineral while those from failed sections are montmorillonitic in nature.

\subsubsection{Grain size distribution}

The results of the grain size distribution analyses are summarized in Table 1. Typical grading curve is presented in Fig. 3. The soils from failed sections have percentage passing No. 200 (0.075 mm) ranging from $41-61 \%$, while those of stable sections ranged from $31-40 \%$. The soils can be classified as well graded soils from the grading curves. It can be observed that the soils from failed sections (F3, F4 and F5) have high proportion of fines $(>57 \%)$ indicating that the soils have the tendency to shrink and swell repeatedly during alternate dry and wet seasons of the humid tropical climatic condition of the southwestern Nigeria, thereby causing distress noticeable on the road. Failures observed in the study area are believed to be caused by pressures developed by the swelling soils. Also, the high clay content of the soils from the failed sections is an indication of their high swelling potential, hence unsuitable for subgrade material. The tested soils of the stable section (S1) have percentage passing $0.075 \mathrm{~mm}$ of more than $35 \%$ with an average of $39 \%$ whereas the soils of stable section (S2) have percentage passing 0.075 $\mathrm{mm}$ of less than $35 \%$ with an average of $33 \%$, generally, rated fair to good subgrade highway material [10]. The soils of the failed sections fall under group A-7-6 of AASHTO classification suggesting poor subgrade material with average fines of $42-59 \%$ (Table 1). The predominance of the fines is responsible for the degree of instability witnessed.

\subsubsection{Consistency limits}

The results of the liquid limit, plastic limit, plasticity index and linear shrinkage tests are summarized in Table 2. The liquid limit, plastic limit and plasticity index of the soils from the failed sections ranged 
from $44-50 \%, 24-27 \%$ and $19-25 \%$ respectively while those from stable sections ranged from $39-$ 40\%, $28-32 \%$ and $7-12 \%$ respectively. According to [15], liquid limit between $35 \%$ and $50 \%$ indicates intermediate plasticity, between $50 \%$ and $70 \%$ high plasticity and between $70 \%$ and $90 \%$ very high plasticity. On the basis of this classification, all the soils are moderately plastic, thereby causing significant deformation under load. The Casagrande chart classification (Fig. 4) also places all the soil samples in the medium plasticity/compressibility region. However, the Ref. [10] specified a maximum liquid limit of $40 \%$ and a maximum plasticity index of $20 \%$ for highway subgrade material. The results showed that the soils from the failed sections are not good subgrade and base material for foundation of pavement structures because of their poor geotechnical properties. Plasticity index tends to have a great influence on the activity of the subgrade soils. The activity values of the studied soils varied from $0.45-$ 1.21 and were classified as inactive to active soil. Activity values of less than 3.00 [16] are showing that the active clay mineral responsible for swelling of the soils is calcium montmorillonite, which is significant due to its harmful effect on engineering structures. The linear shrinkage of the soils from the failed sections varied from $10.7-19.0 \%$. The value is greater than the maximum $8 \%$ recommended by [17], based on this consideration, the soils would be subjective to swelling and shrinkage during alternate dry and wet seasons of the humid tropical climatic condition of the southwestern Nigeria, hence, the soil is unsuitable as both highway sub-base and subgrade material. This must be taken into cognizance by the engineers in the design of the foundation of pavement structures. The linear shrinkage of the soils from the stable sections varied from 5.4 to $8.4 \%$, which is within the recommended value for subsoil material that is good for road construction. The fine soil mixtures from the failed sections contained clay with higher plasticity index and linear shrinkage values than the soil mixtures from the stable sections of the study area. Generally, the lower the linear shrinkage, the lesser the tendency for the soil to shrink when dried [18], thus, this investigation shows that the soils can still be modified by stabilization to achieve the desired specifications.

Table 1. Index properties of the studied soils

\begin{tabular}{|c|c|c|c|c|c|c|c|}
\hline \multirow{2}{*}{$\begin{array}{l}\text { Road } \\
\text { condition }\end{array}$} & \multirow{2}{*}{$\begin{array}{l}\text { Pit } \\
\text { No. }\end{array}$} & \multirow{2}{*}{$\begin{array}{l}\text { Depth } \\
(\mathrm{m})\end{array}$} & \multirow{2}{*}{$\begin{array}{l}\text { Natural } \\
\text { moisture } \\
\text { content range } \\
(\%)\end{array}$} & \multirow{2}{*}{$\begin{array}{l}\text { Specific } \\
\text { gravity } \\
\text { (Gs) range }\end{array}$} & \multicolumn{2}{|c|}{ Size distribution } & \multirow{2}{*}{$\begin{array}{l}\text { AASHTO } \\
\text { classification }\end{array}$} \\
\hline & & & & & $\begin{array}{l}\text { Average } \\
\text { clay-sized } \\
\text { particles (\%) }\end{array}$ & $\begin{array}{l}\text { Average } \\
\text { fines (\%) }\end{array}$ & \\
\hline Failed & F1 & $0.5-2.0$ & $13.1-18.8$ & $2.73-2.76$ & 26.18 & 43.20 & A-7-6 \\
\hline Failed & $\mathrm{F} 2$ & $0.5-2.0$ & $12.3-19.0$ & $2.68-2.81$ & 24.93 & 42.43 & A-7-6 \\
\hline Failed & F3 & $0.5-2.0$ & $12.3-19.5$ & $2.68-2.84$ & 36.25 & 59.10 & A-7-6 \\
\hline Failed & F4 & $0.5-2.0$ & $12.7-19.4$ & $2.58-2.86$ & 37.00 & 58.05 & $A-7-6$ \\
\hline Failed & F5 & $0.5-2.0$ & $12.7-23.3$ & $2.71-2.81$ & 34.38 & 59.48 & A-7-6 \\
\hline Stable & S1 & $0.5-2.0$ & $10.6-12.7$ & $2.73-2.86$ & 23.68 & 39.10 & A-6 \\
\hline Stable & $\mathrm{S} 2$ & $0.5-2.0$ & $11.7-12.2$ & $2.74-2.84$ & 16.38 & 32.68 & A-2-6 \\
\hline
\end{tabular}

Table 2. Consistency limits of the studied soils.

\begin{tabular}{ccccc}
\hline $\begin{array}{c}\text { Pit } \\
\text { No. }\end{array}$ & $\begin{array}{c}\text { Liquid limit range } \\
(\boldsymbol{\%})\end{array}$ & $\begin{array}{c}\text { Plasticity index range } \\
(\boldsymbol{\%})\end{array}$ & $\begin{array}{c}\text { Linear shrinkage range } \\
(\boldsymbol{\%})\end{array}$ & $\begin{array}{c}\text { Activity range of } \\
\text { clay }\end{array}$ \\
\hline F1 & $44.2-46.1$ & $19.3-21.4$ & $11.4-12.9$ & $0.75-0.80$ \\
F2 & $43.9-49.0$ & $18.5-22.8$ & $12.9-19.0$ & $0.73-0.91$ \\
F3 & $44.2-48.3$ & $19.9-23.7$ & $11.4-13.6$ & $0.51-1.10$ \\
F4 & $47.2-48.5$ & $21.7-23.2$ & $10.7-13.6$ & $0.58-0.87$ \\
F5 & $46.4-49.5$ & $19.6-24.9$ & $12.1-13.6$ & $0.60-1.21$ \\
S1 & $39.9-40.3$ & $10.8-12.1$ & $5.4-8.4$ & $0.42-0.51$ \\
S2 & $38.8-40.4$ & $7.4-9.2$ & $7.6-8.3$ & $0.45-0.53$ \\
\hline
\end{tabular}




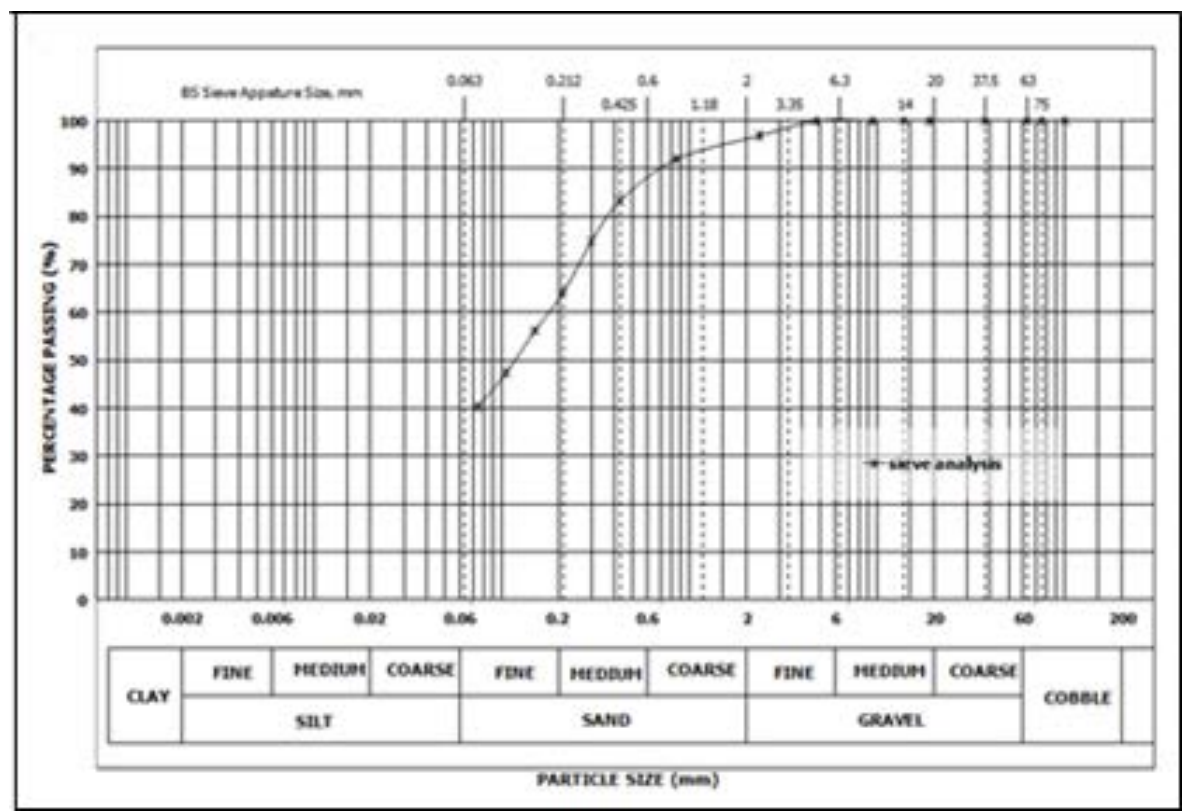

Figure 3. Grain size distribution curve for soil sample taken from Stable section 1 (S1b).

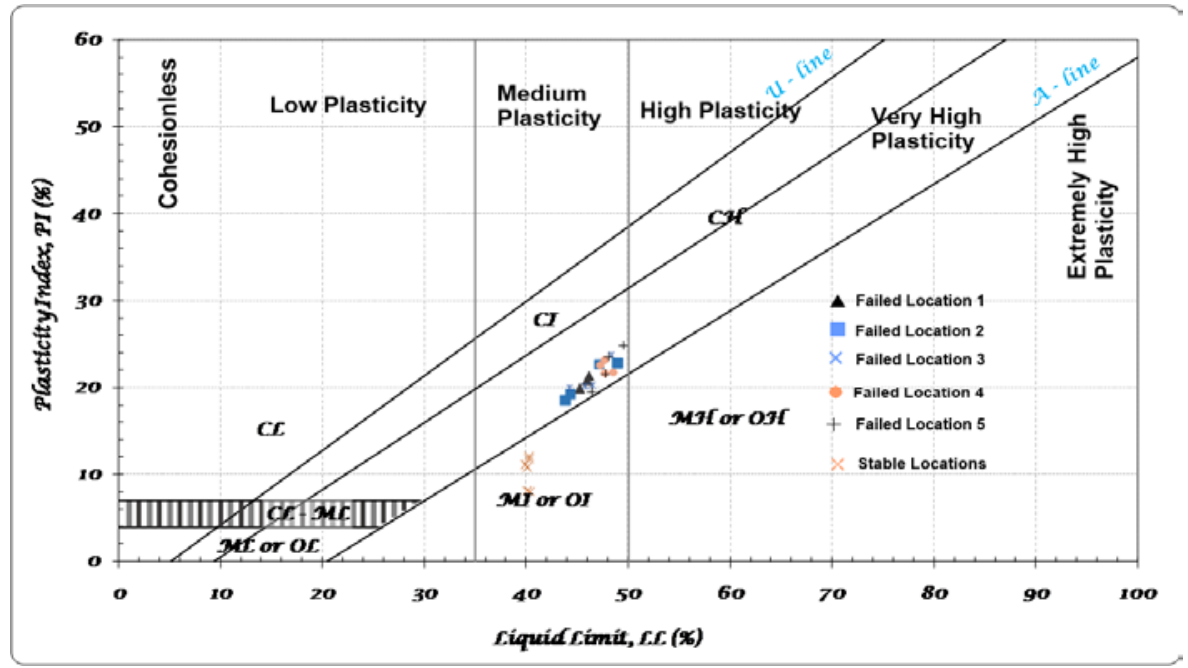

Figure 4. Casagrande chart classification of the soil samples.

\subsection{Engineering Tests}

Results of engineering property test are summarized in Table 3. The resistance of a soil to distress under load is controlled by its strength properties. The strength of the soils sampled was determined by compaction, CBR, unconfined compression test and unconsolidated undrained triaxial test.

\subsubsection{Compaction characteristics}

Compacting soils for roads and airfields requires attaining a high degree of density during construction to prevent detrimental consolidation from occurring under an embankment's weight or under traffic. In addition, compaction reduces the detrimental effects of water. The maximum dry density and optimum moisture content of the lateritic soils at the West African level of compaction are shown in Table 3 and 
Figure 5 shows typical compaction curve. The maximum dry density (MDD) of the soils from failed sections of the highway ranged from $1890-2059 \mathrm{Kg} / \mathrm{m}^{3}$ at optimum moisture content (OMC) of $10.1-$ $15.5 \%$, while those from stable sections ranged from $2069-2096 \mathrm{Kg} / \mathrm{m}^{3}$ (MDD) at $8.1-9.3 \%$ (OMC) (Table 3). These values show that, the soils respond gradually to compaction. However, the best soil for foundation is the soil with high maximum dry density (MDD) at low optimum moisture content (OMC) [18]. The essence of compaction is to improve the desirable load bearing capacity of pavement structures. Failure of civil engineering structures and road pavements increased when the underlying soils are always soaked with water. The results show that the foundation of pavement structures must always be compacted above the MDD and OMC to yield maximum strength, prevent ingress of water and distribute wheel loads uniformly into the pavement structures.

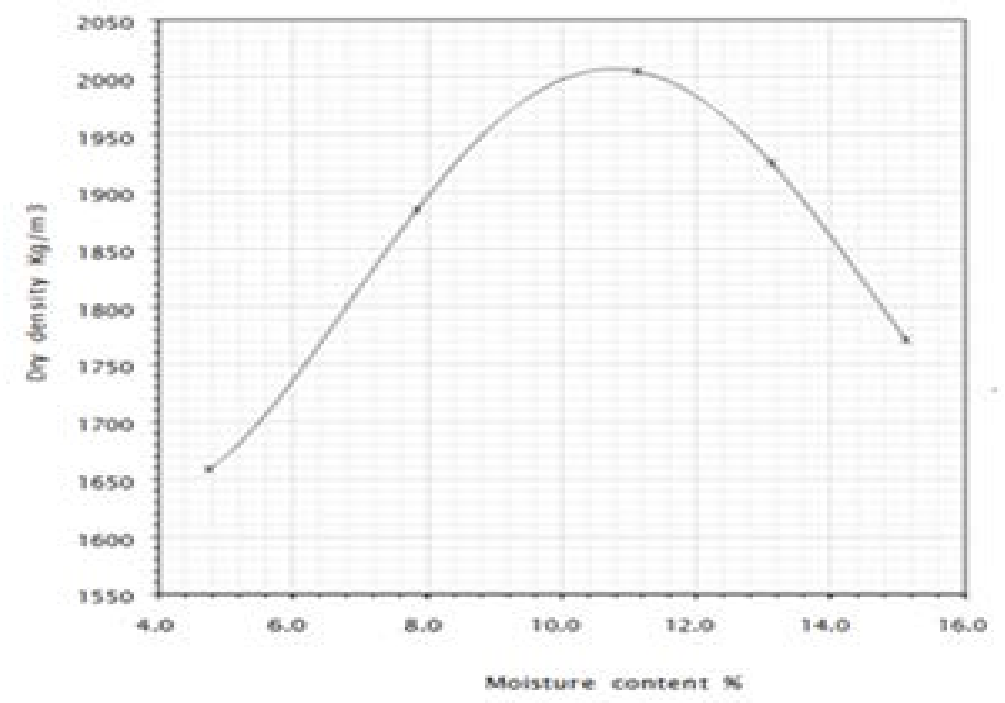

Figure 5. Compaction curve for soil sample taken from failed section 4 (F4d).

\subsubsection{California Bearing Ratio (CBR)}

California bearing ratio is a test used to evaluate soil strength in subgrade, subbase, and base course materials used in road and airfield pavement design. The values of unsoaked and soaked CBR of the soils from the failed sections ranged from $14-32 \%$ and $3-11 \%$ respectively. It shows percentage reduction in strength as a result of soaking of the compacted samples, which ranged from $44-79 \%$ (Table 3). The soaked CBR showed that subgrade soils at failed sections are susceptible to volume change on exposure to excessive moisture. It was observed that unsoaked $(36-43)$ and soaked $(15-23)$ CBR values of samples from stable sections are higher than those from failed sections. None of the analyzed samples have the required $80 \%$ minimum unsoaked and 30\% soaked CBR value recommended for highway sub-base and sub-grade soils by FMWH (2000). The soaked CBR values obtained showed that subgrade soils of the failed sections are liable to critical changes in strength and load bearing capacity as a result of inundation. The CBR values of the study area are generally low, requiring that soil improvement measures would be necessary for stable structures. Ref. [19], reported that the minimum CBR requirements for subgrade, subbase and base courses are $10 \%$ (soaked), 30\% (soaked) and $80 \%$ (unsoaked) respectively. All the soil samples taken from stable sections and only sample F4 taken from the failed section at depth $1.5 \mathrm{~m}$ are within this specification of $10 \%$ minimum value of soaked CBR for subgrade, which means they are adequate as subgrade material.

\subsubsection{Unconfined Compressive Strength (UCS)}

Unconfined Compressive Strength (UCS) is an unconsolidated-undrained test used for clay specimens where the confining pressure $\left(\sigma_{3}\right)$ is zero $(0)$ and the major principal stress $\left(\sigma_{1}\right)$ is the unconfined compressive strength (qu). Consistency of a soil can be expressed not only in terms of Atterberg limits but also in terms of unconfined compressive strengths of soils which in turn determines the strength of the soil. Its value is a measure of suitability of such soil as a foundation material. Table 3 shows the summary of unconfined compressive test results. According to [20], consistency of a clayey soil can be as 
follows; between $0-25 \mathrm{kN} / \mathrm{m}^{2}$ indicates very soft, between $25-50 \mathrm{kN} / \mathrm{m}^{2}$ indicates soft, between $50-100$ $\mathrm{kN} / \mathrm{m}^{2}$ indicates medium, between $100-200 \mathrm{kN} / \mathrm{m}^{2}$ indicates stiff, $200-400 \mathrm{kN} / \mathrm{m}^{2}$ indicates very stiff and greater than $400 \mathrm{kN} / \mathrm{m}^{2}$ indicates hard clay. On this note, consistency of samples from failed sections is stiff while that from stable sections ranges from stiff to very stiff (Table 3 ). Poor subgrade materials are characterized by low stiffness and resistance to deformation which results in pavement failure due to inability to support a high amount of loading [21].

\subsubsection{Shear Strength}

The triaxial test is the most common and important test used to determine the stress-strain properties of soil and shear strength of a soil under controlled drainage conditions. Cell pressures of 30, 60 and 90 $\mathrm{kN} / \mathrm{m}^{2}$ were applied and a maximum deviator stress was obtained at the failure point. Table 4 shows the summary of undrained triaxial test results. Low cohesion $\left(50-75 \mathrm{kN} / \mathrm{m}^{2}\right)$ and frictional angles $(13-$ $17^{\circ}$ ) of the soils of failed sections have a good correlation with its index properties. The low strength will cause failure of pavement under sustained axial loading. The low frictional angle is caused by the presence of swelling clay. Low bearing capacity and low strength characteristics of the soils from failed sections show inadequacy of these materials for use as either a foundation or subgrade material.

Table 3. Strength characteristics of the studied soils

\begin{tabular}{|c|c|c|c|c|c|c|}
\hline $\begin{array}{l}\text { Pit } \\
\text { No. }\end{array}$ & $\begin{array}{l}\text { MDD } \\
\text { range } \\
\left(\mathrm{Kg} / \mathrm{m}^{3}\right)\end{array}$ & $\begin{array}{l}\text { OMC } \\
\text { range } \\
(\%)\end{array}$ & $\begin{array}{l}\text { Unsoaked } \\
\text { CBR range } \\
(\%)\end{array}$ & $\begin{array}{l}\text { Soaked } \\
\text { CBR range } \\
(\%)\end{array}$ & $\begin{array}{l}\text { Percentage } \\
\text { reduction in } \\
\text { strength }(\%)\end{array}$ & $\begin{array}{l}\text { Unconfined } \\
\text { compressive } \\
\text { strength }(\mathrm{kPa})\end{array}$ \\
\hline F1 & $2012-2016$ & $11.4-11.5$ & $14-31$ & $3-9$ & $71-79$ & 148.41 \\
\hline $\mathrm{F} 2$ & 1890-1894 & $15.4-15.5$ & $16-29$ & $4-9$ & $69-75$ & 143.21 \\
\hline F3 & $2027-2046$ & $10.1-11.1$ & $28-32$ & $8-9$ & $71-72$ & 173.35 \\
\hline $\mathrm{F} 4$ & $2005-2013$ & 10.9-11.1 & $15-22$ & $5-11$ & $50-67$ & 149.35 \\
\hline F5 & 2055-2059 & $10.3-10.4$ & $15-17$ & $6-7$ & $59-60$ & 145.91 \\
\hline S1 & 2058-2089 & $8.7-9.3$ & $36-41$ & $15-23$ & $44-58$ & 183.73 \\
\hline $\mathrm{S} 2$ & 2084-2096 & $8.1-8.5$ & $39-43$ & $18-21$ & $51-54$ & 216.01 \\
\hline
\end{tabular}

Table 4. Summary of undrained triaxial test results

\begin{tabular}{ccccc}
\hline Pit No. & Cohesion $\left(\mathbf{k N} / \mathbf{m}^{2}\right)$ & $\begin{array}{r}\text { Angle of internal friction } \\
(\mathbf{\phi})\end{array}$ & $\begin{array}{c}\text { Normal Stress } \\
\left(\mathbf{k N} / \mathbf{m}^{2}\right)\end{array}$ & $\begin{array}{c}\text { Shear Stress } \\
\left(\mathbf{k N} / \mathbf{m}^{2}\right)\end{array}$ \\
\hline F1 & 56.21 & 13 & 134.26 & 87.21 \\
F2 & 75.34 & 17 & 107.34 & 108.16 \\
F3 & 71.16 & 16 & 87.39 & 96.22 \\
F4 & 52.85 & 14 & 105.56 & 79.17 \\
F5 & 49.89 & 17 & 94.17 & 78.68 \\
S1 & 84.98 & 21 & 147.75 & 141.70 \\
S2 & 102.44 & 23 & 122.84 & 154.58 \\
\hline
\end{tabular}

\section{Conclusion}

Lateritic soils typically encountered in the subgrades of south-western Nigeria were investigated by their index and engineering property tests. The samples are generally well graded and they exhibit medium plasticity, which is a possible indication of medium compressibility. The natural moisture content of the analyzed soil samples from the failed sections indicates a high water adsorption capability of the soil material. Hence, good drainage systems should be provided in the area in order to prevent pore water pressures to develop below pavement structures, which could result in significant loss of strength. The higher specific gravity of soils from stable sections shows higher degree of laterization than soils from failed sections. The soils from the failed sections classify in group A-7-6 of the AASHTO classification system, implying poor highway subgrade materials. The interaction of the subgrade and subbase soils with water has greatly reduced shear strengths as shown by the percentage reduction in strength as a 
result of soaking of the compacted samples. The dominance of fines in the lateritic soils, low CBR values and low strength characteristics are responsible for the degree of instability witnessed. However, stabilization will improve the strength for stable structures. Results of this study will be useful in reconstruction works of the failed sections of the road and may guide future pavement design in construction of roads.

\section{References}

1. O. Ademila, "Application of geophysical survey for subsurface investigation of an erected multistory building in southwestern Nigeria," International Basic and Applied Research Journal, 2(12):1-12, 2016.

2. E. A. Meshida, "Highway failure over talc-tremolite schist terrain: a case study of the Ife to Ilesha Highway, southwestern Nigeria," Bulletin of Engineering Geology and Environment. 65:457-461, DOI:10.1007/s10064005- $\quad 0037-7,2006$.

3. M. D. Gidigasu, and D. O. K. Kuma, "Engineering significance of lateritisation and profile development processes,"Proceedings of the Ninth Regional Conference for Africa on soil mechanics and foundation engineering, September. Lagos, Nigeria. 1:3-20, 1987.

4. J. E. Gillot, "Clay in Engineering Geology," Developments in geotechnical engineering. 41, Elsevier: Amsterdam, the Netherlands, 1987.

5. S. S. Adlinge, and A. K. Gupta, "Pavement deterioration and its causes," Journal of Mechanical and Civil Engineering, 9-15, 2010.

6. G. O. Adeyemi, and F. Oyeyemi, "Geotechnical basis for failure of sections of the Lagos-Ibadan expressway, southwestern Nigeria," Bulletin of Engineering Geology and Environment. 59(1):39-45, 2000.

7. M. A. Rahaman, "Review of the basement geology of southwestern Nigeria," In: Kogbe, C.A., (ed) Geology of Nigeria, Rock View (Nig.) Limited, Jos, Nigeria, 39-56, 1989.

8. British Standard (BS) 1377, "Methods of testing soils for civil engineering purposes," British Standards Institution, London, 1990

9. ASTM Standard D1557, "Standard test methods for laboratory compaction characteristics of soil using modified effort," ASTM International West Conshohocken, PA. http://dx.doi.org/10.1520/D1557-09, 2009.

10. Federal Ministry of Works and Housing (FMWH) "General specification for roads and bridges," 2:137-275, 2000.

11. M. Bwalya, "Utilisation and improvement of lateritic gravels in road bases," International Institute for Aerospace Survey and Earth Sciences (ITC), Section Engineering Geology, Kanaalweg 3, 2628 EB, Delft, Netherland, 1998.

12. American Association of State Highways and Transportation Officials (AASHTO), Mil45. Classification of soil andaggregate mixtures of highway for construction purpose, highway materials, 1(1).

13. T. N. Ramamurthy, and T. G. Sitharam, "Geotechnical engineering," S. Chand, New Delhi, 28, 2005.

14. B. M. Das, "Soil mechanics," 3rd ed. Brooks/Cole Publishers, California, 1990.

15. R. Whitlow, "Basic soil mechanics," 3rd ed., Edinburgh Gate, Addison Wesley Longman Limited, 1995.

16. P. B. Attewell, and I. W. Farmer, "Principles of Engineering Geology," Chapman and Hall, London, John Wiley Publication, 7-18, 1976

17. A. C. Madedor, "Pavement design guidelines and practice for different geological area in Nigeria," In: Ola S.A. (ed) Tropical soils of Nigeria in engineering practice. A.A. Balkema, Rotterdam, Netherland, 291-297, 1983.

18. G. Jegede, "Engineering geological significance of the superficial deposits in Carrington Hill area," Country Conc, Ireland. Nigeria Journal of Sciences, 28:153-158, 1999.

19. G. B. Ashworth, and R. T. Overgaard, "Highway planning methods. In highway and traffic engineering in developing countries," (ed. B. Thagesen) Chapman and Hall, London, 1996.

20. B. M. Das, "Fundamentals of geotechnical engineering", 4th ed., USA: Thomson Learning USA. Frias M, and cement and concrete research, 2000.

21. R., Amer, A., Saad, T. A., Elhafeez, H. E. Kady, and M. Madi, "Geophysical and geotechnical investigation of pavement structures and bridge foundations," Austin Journal of Earth Sciences, 1(1):6, 2014. 